\author{
JaCEK BiaŁecki, BARTOSZ Skalski, Beata Olas
}

\author{
Katedra Biochemii Ogólnej \\ Instytut Biochemii \\ Wydział Biologii $i$ Ochrony Środowiska \\ Uniwersytet Łódzki \\ Pomorska 141/143, 90-236 Łódź \\ E-mail: jacek.bialecki@edu.uni.lodz.pl
}

\title{
ROKITNIK ZWYCZAJNY [ELAEAGNUS RHAMNOIDES (L.) A. NELSON] JAKO ŹRÓDŁO ZWIĄZKÓW PROZDROWOTNYCH
}

\section{WSTEP}

Ludzkość na całym świecie zmaga się obecnie $z$ chorobami cywilizacyjnymi, które są poważnym zagrożeniem w krajach rozwiniętych. Naukowcy od lat poszukuja skutecznych środków zapobiegawczych oraz łagodzących objawy chorób układu krążenia czy chorób nowotworowych. W związk $z$ tym, trwaja poszukiwania substancji biologicznie czynnych, które zdolne sa do hamowania, bądź zapobiegania skutkom tych chorób. Dlatego naukowcy coraz częściej badaja substancje zawarte w roślinach, które skrywaja wyjątkowe właściwości. Jedna $z$ roślin, która ostatnio cieszy się szczególnym zainteresowaniem, jest rokitnik zwyczajny [Elaeagnus rhamnoides (L.) A Nelson], który ma właściwości antyoksydacyjne i przeciwzapalne. Uważa się również, że może być stosowany w profilaktyce nowotworowej (TUREK i współaut. 2016). Ponadto, w badaniu przeprowadzonym na myszach zaobserwowano korelacje między spożywaniem liofilizowanego proszku $z$ rokitnika zwyczajnego a dieta wysokotłuszczowa. Dowiedziono, iż spożywanie liofilizowanego proszku ogranicza przyrost tkanki tłuszczowej względem grupy kontrolnej nie pobierajacej preparatu (GuO i współaut. 2020).

Rokitnik zwyczajny należy do roślin $z$ rodziny oliwnikowatych (Elaeagnaceae). $\mathrm{Na}-$ turalnie występuje w miejscach wilgotnych, takich jak wybrzeża morskie czy brzegi rzek. Terenami spełniajacymi warunki do naturalnego wzrostu rokitnika zwyczajnego są: Azja Środkowa, Mongolia, Chiny, Syberia, Kaukaz i Europa. Na skale przemysłowa upra- wiany jest głównie w Rosji, Chinach, Niemczech, Finlandii i Estonii oraz w Polsce, np. w okolicach wybrzeża Morza Bałtyckiego czy na Suwalszczyźnie. Warto podkreślić, że rokitnik zwyczajny od 2014 r. jest w Polsce pod częściowa ochrona zgodnie $z$ rozporządzeniem Ministra Środowiska. Możliwy jest zbiór owoców, jeśli nie odbywa się w obrębie siedlisk wydmowych i klifowych, a krzewy nie sa niszczone (MALINOWSKA i OlAS 2016, ULANOWSKA i współaut. 2018).

Elaeagnus rhamnoides jest silnie rozgałezionym krzewem liściastym osiagajacym $4 \mathrm{~m}$. Jego dość rozległe korzenie wchodza w symbioze $z$ bakteriami nitryfikujacymi anaerobowymi, dzięki czemu jest $\mathrm{w}$ stanie rosnać na terenach dość wymagajacych, np. piaszczystych. Owoce moga przyjmować barwę od żółtej po pomarańczową i osiagaja średnice do $10 \mathrm{~mm}$. Mią̇̇sz owoców ma specyficzny kwaśny, cierpki i gorzki smak. Zawiera on 74 lotne zwiazki, w tym estry, alkohole, terpeny, aldehydy, ketony takie jak: oktanian etylu, dekanol, dekanian etylu i dodekanian etylu, które wpływaja na unikatowy zapach przypominajacy cytrusy lub jagody. Skandynawowie oceniaja, że zapach owoców rokitnika zwyczajnego przypomina ananasa (TUREK i współaut. 2016, BOŚKO i BIEL 2017).

\section{OWOC ROKITNIKA JAKO OWOC}

EGZOTYCZNY O DUŻEJ ZAWARTOŚCI

ZWIAZKÓW ANTYOKSYDACYJNYCH

Ze względu na wyjątkowy skład chemiczny owoce rokitnika zwyczajnego sa zaliczane 
do owoców egzotycznych o naturalnie zwiększonej zawartości niektórych zwiazków biologicznie czynnych. Poza rokitnikiem, również inne egzotyczne owoce jak: aronia, goja, marakuja czy acerola, maja zwiększona zawartość witamin, minerałów (mikro i makroelementów), aminokwasów, nienasyconych kwasów tłuszczowych oraz związków przeciwutleniajacych i antyoksydacyjnych (PIŁAT i ZADERNOWSKI 2019; TUREK i współaut. 2016, BANACH i współaut. 2017).

Można wyróżnić kilka odmian rokitnika zwyczajnego charakteryzujacych się zmienna zawartościa związków biologicznie czynnych. Jedną $z$ odmian rokitnika zwyczajnego jest Plamiennaja, która występuje w Rosji/Białorusi i jest mrozoodporna. Natomiast również mrozoodporna odmiana Pollmix, występujaca w Niemczech, może być uprawiana na glebach ubogich w składniki odżywcze. Znane sa także odmiany Askola, Botaniczeskaja, Frugana czy Nivelnaja (BIENIEK i współaut. 2007, SZYMCZAK 2020).

Rokitnik charakteryzuje się najwyższa zawartością kwasu L-askorbinowego (witaminy C), zawiera bowiem aż do $1005 \mathrm{mg} / 100 \mathrm{~g}$ owoców (odmiana nadbałtycka) - dla porównania goja zawiera około $49 \mathrm{mg} / 100 \mathrm{~g}$, natomiast aronia od 1,3 do $27 \mathrm{mg} / 100 \mathrm{~g}$ (Tabeli 1). Ponadto E. rhamnoides (L.) A. Nelson zawiera znaczna ilość tokoferoli (witaminy E), aż $10 \mathrm{mg} / 100 \mathrm{~g}$, co oznacza, że może być stosowany w celu zapobiegania przedwczesnej apoptozie (programowanej smierci komórek) wskutek działania stresu oksydacyjnego.

\section{ZWIAZKI CHEMICZNE ZAWARTE W OWOCACH, LISCIACH ORAZ NASIONACH ROKITNIKA ZWYCZAJNEGO}

Rokitnik zwyczajny ze względu na swój wyjątkowy skład chemiczny stał się przedmiotem licznych badań. Roślina ta doskonale sprawdza się jako dodatek uzupełniajaccy dzienna dawkę zapotrzebowania na witaminy takie jak: $\mathrm{C}, \mathrm{E}, \mathrm{D}, \mathrm{K}_{1}, \mathrm{~B}$ (tiamina $\left(\mathrm{B}_{1}\right)$, ryboflawina $\left(\mathrm{B}_{2}\right)$, pirydoksyna $\left(\mathrm{B}_{6}\right)$, kwas foliowy $\left(\mathrm{B}_{9}\right)$. Poza witaminami, w owocach rokitnika możemy znaleźć również makro- i mikroelementy (Mn, Mg, K, Ca, Fe, $\mathrm{Na}, \mathrm{Zn}$, $\mathrm{Ni}$, zwiazki fenolowe, lipidy [w tym kwasy tłuszczowe nienasycone: kwas oleinowy (typu omega 9), kwas linolowy (typu omega 6), kwas a-linolenowy (typu omega 3), kwas oleopalmitynowy (typu omega 7); kwasy tłuszczowe nasycone: kwas palmitynowy], kwasy organiczne (jabłkowy, cytrynowy, izocytrynowy, szczawiowy, winowy, chinowy), cukry (fruktoza, ramnoza, sorbitol, glukoza), białka, kartenoidy ( $\beta$-karoten, likopen, zeaksantyna) i pektyny. Zawartość i występowanie poszczególnych substancji bioaktywnych może się różnić w zależności od metody składowania owoców, ich wielkości, dojrzałości, metod przetwarzania (soków, olejów) czy warunków, w jakich rozwijała się roślina (MALINOWSKA i OlAS 2016). Nie zmienia to jednak faktu, że przez bogactwo prozdrowotnych substancji owoce rokitnika sa wykorzystywane w przemyśle do wytwarzania soków i olejów, które moga być używane w celu urozmaicenia i uzupełnienia diety.

Tabela 1. Porównanie zawartości niektórych zwiazków bioaktywnych występujących naturalnie w owocach egzotycznych. (KULCZYŃski i GRAMZA-MichaŁOWsKa 2016, Szopa i współaut. 2017, UlANOwSKA i współaut. 2018).

\begin{tabular}{llll}
\hline Wybrane substancje bioaktywne & $\begin{array}{l}\text { Rokitnik zwyczajny }(\mathrm{mg} / 100 \mathrm{~g} \\
\text { owoców) }\end{array}$ & $\begin{array}{l}\text { Goja (mg/100 g } \\
\text { owoców) }\end{array}$ & $\begin{array}{l}\text { Aronia (mg/100 g } \\
\text { owoców) }\end{array}$ \\
\hline Wapń & $5,0-7,2$ & 50 & 32,2 \\
Potas & 219 & 1460 & 218 \\
Żelazo & $0-0,25$ & 5,5 & 0,93 \\
Fosfor & 84,2 & 184 & brak danych \\
Magnez & 9 & $9 * 10^{4}$ & 16,2 \\
Witamina C & 600 & 48,94 & $1,3-27$ \\
Witamina $B_{1}$ & $0,02-0,04$ & 0,15 & 0,02 \\
Witamina $B_{2}$ & $0,03-0,05$ & 1,27 & 0,02 \\
Witamina E & 10 & brak danych & $0,8-31$ \\
Błonnik & brak danych & 7780 & 5600 \\
\hline
\end{tabular}


Jednak nie tylko owoce rokitnika sa bogate $\mathrm{w}$ związki biologicznie aktywne. Liście i nasiona również zawierają ogromne ilości witamin oraz mikro- i makroelementów. Liście rokitnika maja w swoim składzie: leukoantocyjanidyny, flawonole, (-)epikatechiny, (+) galokatechiny, (-)epigalokatechiny oraz kwas galusowy, co czynie je idealnym dodatkiem do herbat ziołowych (SKALSKI i współaut. 2018). Ponadto, zawieraja chlorofil, karotenoidy, aminokwasy (takie jak: lizyna, metionina, cysteina), katechinę, estryfikowane sterole oraz triterpeny, których brak w owocach rokitnika (PIŁAT i ZADERNOWSKI 2016). Natomiast nasiona zawieraja mniejsza niż owoce czy liście ilość substancji biologicznie czynnych. Sa to: a-tokoferol (witamina E) i kwas foliowy (witamina $B_{9}$ ), mikro i makroelementy, karotenoidy, zwiazki fenolowe, aminokwasy (tylko niebiałkowe), lipidy (nie występuje kwas oleopalmitynowy), białka, cukry i pektyny (PIEAT i ZADERNOWSKI 2019). Ponadto wykazano, że w skórce łodyg i owo- ców występuje serotonina (5-hydroksytryptamina) wykazująca liczne funkcje biologiczne, która jest także stosowana $\mathrm{np}$. $\mathrm{w}$ razie dolegliwości związanych $z$ układem moczowym (PIEAT i ZADERNOWSKI 2019).

Witaminy są niskocząsteczkową grupą związków organicznych, o zróżnicowanej budowie chemicznej, które sa niezbędne do prawidłowego przeprowadzenia wielu procesów metabolicznych. Sa to zwiazki egzogenne, co oznacza, że ludzki organizm nie może ich zsyntetyzować, a więc musza być pobierane $z$ pożywieniem. W przypadku braku określonych witamin w organizmie może dojść do rozwinięcia się choroby zwanej awitaminoza. Istnieje jednak pewne grupa witamin, które moga być zsyntetyzowane $z$ prekursorów witamin zwanych prowitaminami. Przykładem jest witamina A powstająca $z$ karotenoidów. Podkreślić należy, że w owocach rokitnika znajduje się ich aż do 500 $\mathrm{mg} / 100 \mathrm{~g}$ owoców (Tabela 2). Witaminy takie jak K lub B moga być także syntetyzo-

Tabela 2. Zawartość poszczególnych zwiazków bioaktywnych w owocach rokitnika zwyczajnego, na 100 g owoców oraz ich dzienne zapotrzebowanie dla mężczyzn i kobiet w wieku powyżej 19 lat (WILCZYŃSKA i RETEL 2011, JAROSZ i współaut. 2017; UlANOwsKA i współaut. 2018, TKACZ i współaut. 2019).

\begin{tabular}{|c|c|c|c|}
\hline $\begin{array}{l}\text { Substancje zawarte w } \\
\text { owocach rokitnika }\end{array}$ & $\begin{array}{l}\text { Zawartość związków biolo- } \\
\text { gicznie czynnych w mg na } \\
100 \text { g owoców }\end{array}$ & $\begin{array}{l}\text { Zalecane dzienne spożycie } \\
\text { dla mężczyzny w wieku } \\
\text { >19 lat (mg) }\end{array}$ & $\begin{array}{l}\text { Zalecane dzienne spoży- } \\
\text { cie dla kobiety w wieku } \\
>19 \text { lat }(\mathrm{mg})\end{array}$ \\
\hline Witamina $\mathrm{C}$ & 600 & 90 & 75 \\
\hline Witamina $\mathrm{E}$ & 10 & 10 & 8 \\
\hline Witamina $\mathrm{B}_{1}$ & $0,02-0,04$ & 1,3 & 1,1 \\
\hline Witamina $\mathrm{B}_{2}$ & $0,03-0,05$ & 1,3 & 1,1 \\
\hline Witamina $\mathrm{B}_{6}$ & 0,08 & 1,3 & 1,3 \\
\hline Witamina $\mathrm{B}_{9}$ & 0,79 & 0,4 & 0,4 \\
\hline Witamina $\mathrm{K}_{1}$ & $0,90-15$ & 65 & 55 \\
\hline kw. jabłkowy & $960-2870$ & Brak danych & \\
\hline kw. cytrynowy & $10-100$ & Brak danych & \\
\hline kw. izocytrynowy & $20-210$ & Brak danych & \\
\hline kw. szczawiowy & $10-20$ & Brak danych & \\
\hline kw. chinowy & $70-1140$ & Brak danych & \\
\hline ramnoza & $40-60$ & & \\
\hline fruktoza & $40-100$ & $13 * 10^{4}$ & \\
\hline sorbitol & $70-140$ & & \\
\hline glukoza & $1210-2660$ & & \\
\hline karotenoidy & $46,61-508,57$ & Brak danych & \\
\hline kw. fenolowe & $5,18-8,94$ & $250-500$ & \\
\hline
\end{tabular}


Tabela 3. Procentowa zawartość kwasów tłuszczowych w owocach rokitnika zwyczajnego (TKACZ i współaut. 2019, zmodyfikowano).

Kwasy tłuszczowe zawarte w rokitniku

Procentowa zawartość poszczególnych kwasów tłuszczowych w owocach rokitnika $\mathrm{w} \%$

kwas oleinowy

kwas linolowy

kwas a-linolenowy

kwas oleopalmitynowy

kwas palmitynowy
$12,91-17,83$

$13,16-20,13$

$2,95-4,49$

$23,67-31,25$

$32,00-38,19$ wane przez mikrobiom układu pokarmowego (SROKA i współaut. 2005). Owoce rokitnika zwyczajnego pokrywaja dzienne zapotrzebowanie mężczyzn i kobiet powyżej 19 roku życia na witaminy: C, E i $\mathrm{B}_{9}$ (Tabela 2). Witamina $\mathrm{C}$ jest antyoksydantem, ponadto pełni w organizmie wiele funkcji np.: neutralizuje powstałe wolne rodniki, jest kofaktorem licznych enzymów (np. dla hydrolaz, oksygenaz) czy bierze udział $\mathrm{w}$ wielu procesach metabolicznych m.in. syntezie adrenaliny $z$ tyrozyny (URBANIAK $i$ współaut. 2019). Witamina E również jest silnym przeciwutleniaczem, chroni przed peroksydacją (utlenieniem) lipidów błon komórkowych. Jako antyoksydant ma też właściwości antykancerogenne i antymutagenne. Potocznie nazywana jest „witamina młodości”, ponieważ hamuje proces starzenia się skóry (CZERWONKA i współaut. 2019). Witamina $B_{9}$ (kwas foliowy) uważana jest za jedna $z \quad 13$ witamin niezbędnych do prawidłowego funkcjonowania organizmu człowieka. Uczestniczy w metabolizmie aminokwasów i kwasów nukleinowych oraz bierze udział w syntezie neuroprzekaźników (BANYŚ i współaut. 2020)

Zwiazki fenolowe pochodzenia roślinnego, wraz z flawonoidami należa do polifenoli. Polifenole zawieraja co najmniej dwie grupy hydroksylowe przyłączone do pierścienia aromatycznego, co warunkuje ich wyjątkowe właściwości. Uczestniczą $\mathrm{w}$ reakcjach redox oraz pełnia funkcje: przeciwnowotworowe, przeciwutleniające (redukuja peroksydację lipidów błonowych), przeciwzapalne, przeciwmiażdżycowe oraz, u pacjentów $z$ chorobami sercowo-naczyniowymi, przeciwplytkowe (SKALSKI i współaut. 2018, GAŁAZKKA-CZARNECKA i współaut. 2019). Rokitnik zwyczajny zawiera ich do $9 \mathrm{mg} / 100 \mathrm{~g}$ owoców (Tabela 2). Nie jest to jednak wystarczajaca wartość dziennego zapotrzebowania na zwiazki fenolowe dla dorosłego człowieka, ponieważ powinna ona wynosić od $250 \mathrm{mg}$ do $500 \mathrm{mg}$.

Kwasy tłuszczowe dziela się na dwie grupy: kwasy nasycone i nienasycone. Nasyco- ne kwasy maja negatywny wplyw na organizm człowieka, w tym na funkcjonowanie błon komórkowych; należy do nich m.in. kwas palmitynowy. Natomiast nienasycone kwasy mają właściwości prozdrowotne, obniżaja zawartość frakcji LDL cholesterolu oraz pełnia ważne funkcje metaboliczne i hormonalne. Należa do nich: kwas oleinowy, linolowy, a-linolenowy i oleopalmitynowy. Wśród nienasyconych kwasów tłuszczowych można wyróżnić kwasy egzogenne, które musza być dostarczane wraz $z$ pożywieniem do prawidłowego funkcjonowania organizmu. Do grupy tej należą m.in. kwasy omega 3, czyli kwas a-linolenowy, eikozapentaenowy czy dokozaheksaenowy (RUDZIŃSKA i PRZYBYLSKI 2019). Rokitnik jest bogatym źródłem zarówno jednonienasyconych (MUFA), jak i wielonienasyconych (PUFA) kwasów tłuszczowych. W swoim składzie zawiera od $13 \%$ do $18 \% \mathrm{kw}$. oleinowego (MUFA), od 13\% do $20 \% \mathrm{kw}$. linolowego (PUFA), od 3\% do $4,5 \%$ kw. a-linolenowego (PUFA) oraz od $24 \%$ do $31 \% \mathrm{kw}$. oleopalmitynowego (MUFA) (Tabela 3). Tak więc stosunek kwasów jednonienasyconych do kwasów wielonienasyconych $\mathrm{w}$ rokitniku zwyczajnym wynosi 37\%-49\% (MUFA) do 16\%-24,5\% (PUFA). Podobny udział kwasów tłuszczowych nienasyconych możemy zaobserwować $\mathrm{w}$ tłuszczu tkanki mięśniowej ryb. Dla przykładu: okoń (Perca fluviatilis) zawiera 38,9-39,6\% (MUFA) i 18,1-29,6\% (PUFA), również karp (Ciprinus carpio) wykazuje podobny stosunek kwasów nienasyconych wynoszacy $51,1 \%$ (MUFA) do 21,9\% (PUFA). (KALINIAK i współaut. 2015, RUDZIŃSKA i PRZYBYLSKI 2019). Rokitnik zawiera więc stosunkowo mało kwasów nasyconych, przy jednocześnie wysokiej procentowej zawartości kwasów nienasyconych (Tabela 3). Ponadto, zawiera do $4,5 \%$ egzogennego kwasu a-linolenowego i dlatego osoby $z$ wysoka wartościa frakcji LDL lub $z$ niedoborem egzogennych kwasów omega-3 powinny stosować preparaty suplementacyjne $z E$. rhamnoides (L.) A. Nelson. 


\section{WŁAŚCIWOŚCI PROZDROWOTNE ROKITNIKA ZWYCZAJNEGO}

Elaeagnus rhamnoides (L.) A. Nelson jest roślina wykorzystywana w celach leczniczych już od czasów starożytnych. Grecy wykorzystywali młode pędy i liście do karmienia zwierzat, co prowadziło do wzrostu ich masy. Dodatkowo, zwłaszcza u koni, sierść była bardziej lśniąca i zdrowsza (MALINOwSKA i OLAS 2016). Rokitnik zwyczajny był również wykorzystywany w medycynie tybetańskiej w celu poprawy krażenia krwi, usuwania skrzepów, a także do łagodzenia objawów chorobowych, takich jak kaszel czy biegunka. W Mongolii rokitnik stosowany był jako srodek uspokajajacy i wspomagajacy proces gojenia się ran (BoŚKo i BIEL 2017).

Rokitnik znany już od czasów starożytnych, jest nadal roślina wykorzystywana w różnych gałęziach przemysłu: farmaceutycznym, kosmetycznym i spożywczym (wyrób soków, suszonych owoców, olejów), a także jako substytut pomocny przy rekultywacji gleb, produkt opałowy i dekoracyjny.

Jednak to jego właściwości prozdrowotne powoduja, że cieszy się obecnie dużym zainteresowaniem naukowców jako produkt do tworzenia suplementów skutecznych w leczeniu wielu chorób cywilizacyjnych (Tabela 4). Sa to właściwości: antyoksydacyjne, przeciwkancerogenne, przeciwmutagenne, hepatoochronne, przeciwbakteryjne i przeciwwiru- sowe, kardioochronne, przeciwmiażdżycowe, przeciwcukrzycowe i przeciwzapalne. Wspomaga także odporność nieswoista, przyśpiesza gojenie się ran i łagodzi objawy starzenia (PIEAT i ZADERNOWSKI 2016, UlaNOWSKA i współaut. 2018).

\section{PRODUKTY Z ROKITNIKA O DZIAEANIU PROZDROWOTNYM}

Obecnie na rynku znajduje się wiele preparatów $z$ rokitnika zwyczajnego: oleje $z$ nasion, soki i wyciagi $z$ owoców i miaższu, suszone owoce, mus $z$ całych owoców, herbaty $z$ kory i liści, dżemy $z$ owoców, liofilizowane proszki $z$ owoców, miód rokitnikowy oraz ekstrakty wodno-etanolowe $z$ owoców (zagęszczony preparat $z$ owoców rokitnika, otrzymany poprzez wcześniejsze wytrawienie odpowiednich związów przez rozpuszczalniki) (PILAT i ZADERNOWSKI 2016, ULANOWSKA i współaut. 2018).

Każdy $z$ tych produktów posiada znaczne ilości związków bioaktywnych. Jak pokazuja dane $\mathrm{w}$ Tabeli 5, sok $\mathrm{z}$ rokitnika zawiera prawie tyle samo tłuszczów co węglowodanów, a więc może być przydatny dla osób $z$ dieta ketogeniczna. $\mathrm{W}$ diecie tej minimalizuje się przyswajanie węglowodanów (zarówno cukrów prostych, jak i złożonych), by zmusić organizm do wykorzystywania tłuszczu jako głównego źródła energii. Stąd też sok $z$

Tabela.4. Właściwości i działanie lecznicze wybranych związków biologicznie czynnych zawartych w owocach, liściach czy nasionach rokitnika zwyczajnego (PIŁAT i ZADERNOWSKI 2016, ULANOwSKA i współaut. 2018).

\begin{tabular}{|c|c|c|}
\hline Substancja czynna & Część rośliny & Działanie i właściwości lecznicze \\
\hline Witamina $\mathrm{C}$ & Owoce & $\begin{array}{l}\text { Przeciwutleniające, zapobiegające uszkodzeniom błon komórko- } \\
\text { wych, wspomagające syntezę kolagenu }\end{array}$ \\
\hline Witamina $\mathrm{K}$ & Owoce & $\begin{array}{l}\text { Zapobiegajace krwawieniom, przyspieszajace gojenie ran, prze- } \\
\text { ciwwrzodowe }\end{array}$ \\
\hline Witaminy $z$ grupy B & Owoce, liście, nasiona & Stymulujące odnowę komórek \\
\hline Karotenoidy & Owoce, liście, nasiona & $\begin{array}{l}\text { Przeciwutleniające, wspomagające syntezę kolagenu, przyspie- } \\
\text { szające epitelializację (przesuwanie komórek naskórka z obwo- } \\
\text { du rany do jej środka, wykorzystując jako podłoże utworzoną } \\
\text { ziarninę) }\end{array}$ \\
\hline Tokoferole & Owoce, liście, nasiona & $\begin{array}{l}\text { Przeciwutleniające, łagodzące ból, ochronne przed zmianami } \\
\text { zwyrodnieniowymi, zakrzepami, skurczami mięśni }\end{array}$ \\
\hline $\begin{array}{l}\text { Wielonienasycone } \\
\text { kwasy tłuszczowe }\end{array}$ & Owoce, liście, nasiona & $\begin{array}{l}\text { Immunoregulujące, neuroochronne, przeciwnowotworowe, kar- } \\
\text { dioochronne, przyśpieszające gojenie się ran }\end{array}$ \\
\hline Kwasy organiczne & Owoce & $\begin{array}{l}\text { Zmniejszające ryzyko zawału serca i udaru mózgu, przeciwwrzo- } \\
\text { dowe, przeciwreumatyczne, przyspieszające gojenie się ran }\end{array}$ \\
\hline Związki polifenolowe & Owoce, liście, nasiona & $\begin{array}{l}\text { Przeciwutleniające, cytoochronne, kardioochronne, przyspieszają- } \\
\text { ce gojenie ran }\end{array}$ \\
\hline
\end{tabular}


Tabela 5. Wykaz wartości odżywczych soków z rokitnika, jabłka, marchwi oraz pomidorów na $100 \mathrm{ml}$ produktu.

\begin{tabular}{|c|c|c|c|c|}
\hline & $\begin{array}{l}\text { Sok } 100 \% \text { z owoców } \\
\text { rokitnika }\end{array}$ & Sok jabłkowy 100\% & Sok z marchwi 100\% & $\begin{array}{l}\text { Sok z pomidorów } \\
100 \%\end{array}$ \\
\hline Wartość energetyczna & $39 \mathrm{kcal}$ & $46 \mathrm{kcal}$ & $33 \mathrm{kcal}$ & $17 \mathrm{kcal}$ \\
\hline Tłuszcze & $<2,1 \mathrm{~g}$ & Og & $0,34 \mathrm{~g}$ & Og \\
\hline $\begin{array}{l}\mathrm{W} \text { tym } \mathrm{kw} \text {. tłuszczowe } \\
\text { nasycone }\end{array}$ & $<0,2 \mathrm{~g}$ & Og & $0,04 \mathrm{~g}$ & $\mathrm{Og}$ \\
\hline Węglowodany & $2,5 \mathrm{~g}$ & $11,5 \mathrm{~g}$ & $7,2 \mathrm{~g}$ & $2,7 \mathrm{~g}$ \\
\hline W tym cukry proste & $2,3 \mathrm{~g}$ & $11,5 \mathrm{~g}$ & $3,1 \mathrm{~g}$ & $2,4 \mathrm{~g}$ \\
\hline Białko & $0,7 \mathrm{~g}$ & Og & $1,2 \mathrm{~g}$ & $0,9 \mathrm{~g}$ \\
\hline Sól (NaCl) & $<0,01 \mathrm{~g}$ & $0 g$ & $0,12 \mathrm{~g}$ & $0,6 \mathrm{~g}$ \\
\hline
\end{tabular}

rokitnika, który w $100 \mathrm{ml}$ zawiera aż 2,1 g tłuszczu, na $2,5 \mathrm{~g}$ węglowodanów, jest preferowany w stosunku do innych soków, w których zawartość węlowodanów jest znacznie wyższa, przy minimalnej lub zerowej zawartości tłuszczów (WILSON i LOWERY 2017).

Ze względu na niewielka zawartość węglowodanów sok $z$ rokitnika może być stosowany także przez osoby $z$ cukrzyca jako alternatywa dla innych naturalnych soków owocowych.

Oleje $z$ rokitnika zwyczajnego sa wykorzystywane nie tylko w przemyśle spożywczym, lecz także w kosmetologii przy tworzeniu preparatów do pielęgnacji skóry, dzięki właściwościom odnawiającym, odżywczym, przeciwzmarszczkowym, przeciwzapalnym i promieniochronnym. Dodatkowo, doskonale wchłaniaja się w skórę nie powodując uczucia „tłustości”. Likwidują również przebarwienia skóry dzięki znacznej ilości witaminy C i flawonoidów. E. rhamnoides (L.) A. Nelson wykorzystywany jest także do produkcji preparatów do opalania, jako naturalny filtr ochronny przed promieniowaniem UVA i UVB. Preparaty rokitnikowe moga być stosowane do ochrony niemal każdej cery i skóry, począwszy od skóry dojrzałej, suchej, wrażliwej, kończac na skórze dotkniętej trądzikiem. Najczęściej występuje w produktach przeciwzmarszczkowych i przeciwstarzeniowych dzięki swoim właściwościom przeciwutleniajacym (ujędrnia i usztywnia skórę, wygładza zmarszczki) (RESICH-KOZIEŁ i NIEMYSKA 2020).

\section{WŁAŚCIWOŚCI ANTYOKSYDACYJNE}

Właściwości przeciwutleniające przypisuje się głównie zwiąkom fenolowym (flawonoidy, kwasy fenolowe), występujacym w nasio- nach, liściach, ale głównie w owocach rokitnik zwyczajnego. Ich stężenie zależne jest od dojrzałości danego organu; im mniej jest on dojrzały, tym związków fenolowych jest więcej (BośKo i BIEL 2017). Wyróżniono 17 postaci kwasów fenolowych w tym m.in.: kwas galusowy, pochodne kwasu hydroksybenzoesowego, pochodne kwasu hydroksycynamonowego, kwas salicylowy, kwas p-kumarowy i kwas chinowy. Natomiast do flawonoidów należą m.in.: izoramnetyna, rutyna, kwercetyna, kemferol, (+) katechina. Polifenole, poza właściwościami antyoksydacyjnym, pełnia również istotna rolę $\mathrm{w}$ stabilizacji kwasu askorbinowego (ULANOWSKA i współaut. 2018). Tokoferol, karotenoidy i kwas askorbinowy, które znajduja się w owocach rokitnika, również wykazuja właściwości przeciwutleniajace.

Flawonoidy i kwasy fenolowe sa podstawowymi składnikami, które wiaża reaktywne formy tlenu takie jak: rodnik ponadtlenkowy $\left(\mathrm{O}_{2}^{-}\right)$, rodnik hydroksylowy $(\cdot \mathrm{OH})$ czy nadtlenek wodoru $\left(\mathrm{H}_{2} \mathrm{O}_{2}\right)$. Udowodniono, że owoce rokitnika podawane $\mathrm{w}$ diecie $\mathrm{w}$ postaci żywności, suplementów lub ekstraktów alkoholowych, maja efekty przeciwutleniajace i przeciwnowotworowe. Chronia komórki przed uszkodzeniami oksydacyjnymi, a w ich następstwie do pojawienia się zmian prowadzacych do rozwinięcia się choroby nowotworowej. Ponadto znacząco zmniejszaja peroksydację lipidów, w wyniku których powstaja reaktywne formy lipidów uszkadzajace błony komórkowe (SKALSKI i współaut. 2019).

\section{WŁAŚCIWOŚCI HAMUJACE KANCEROGENEZE I ANTYMUTAGENNE}

Flawonoidy chronią komórki przed uszkodzeniami oksydacyjnymi, w konsekwencji - 
przed powstaniem mutacji spontanicznych, a wraz $z$ tym zabezpieczaja przed powstaniem zmodyfikowanych wersji puryn czy pirymidyn takich jak: 8-okso-7,8-dihydrodeoksyguanina, 5-hydroksymetylocytozyna (nazywana również szóstą zasadą azotowa), 5-hydroksymetylouracyl czy glikol tyminy.

Wykazano również, że flawonoidy wyizolowane $z$ owoców rokitnika, powoduja apoptoze komórek nowotworowych watroby linii BEL-7402 i hamuja wzrost komórek białaczki linii HL 60. Jednak mechanizm ich działania nie jest jednakowy. Kwercetyna czy kemferol wywołuja zmiany morfologiczne w jadrze, w tym m.in. kondensację chromatyny, doprowadzajac ostatecznie do apoptozy komórek nowotworowych. Izoramnetyna i syringetyna nie indukuja apoptozy, jednak pomimo użycia tych samych stężeń silniej hamuja rozwój komórek HL-60, dzięki obecności funkcyjnej grupy metoksylowej (ULANOWSKA i współaut. 2018).

Ponadto, ekstrakt $z$ liści rokitnika wykazuje właściwości przeciwnowotworowe wobec komórek ostrej białaczki szpikowej linii KG-1a, HL 60 i U937. Najbardziej wrażliwy na zahamowanie proliferacji okazały się komórki linii HL 60. Jego proliferacja została zahamowana już przy stężeniu $25 \mu \mathrm{g} / \mathrm{ml}$, natomiast proliferacja linii KG-1a i U937 została zahamowana przy $100 \mu \mathrm{g} / \mathrm{ml}$ (ULANowSKA i współaut. 2018).

\section{WŁAŚCIWOŚCI HEPATOOCHRONNE}

Odkryto również, że rokitnik zwyczajny przeciwdziała powstawaniu benzopirenu i dimetylobenzenoantracenu (DMBA), które wywołuja brodawczaka skóry. Zahamowanie ich powstawania jest możliwe poprzez stymulację aktywności enzymów II fazy (transferaza S-glutationu oraz DT-diaforaza) oraz enzymów przeciwutleniajacych (dysmutaza ponadtlenkowa, katalaza, peroksydaza glutationowa, reduktaza glutationowa) występujacych w watrobie (UlANOWSKA i współaut. 2018).

Preparaty, takie jak oleje $z$ rokitnika, sa świetnym źródłem bioaktywnych związków o właściwościach leczniczych i ochronnych dla watroby. Co więcej, zmniejszaja szkody wywołane przez aflatoksyny B1 (mykotoksyny wytwarzane przez grzyby $z$ rodzaju Aspergillus), które sa wysoce toksyczne, oporne na temperaturę i występuja między innymi w: zbożu, suszonych owocach, orzechach laskowych i brazylijskich, a nawet (w odpowiednich warunkach) w chlebie (KowALSKA i współaut. 2017, UlANOwsKA i współaut. 2018).

Elaeagnus rhamnoides (L.) A. Nelson zapobiega również aktywacji takich enzymów jak: aminotransferaza alaninowa, aminotransferaza asparaginowa czy fosfataza alkaliczna, których zwiększona obecność świadczy o uszkodzeniach watroby (UlANOwSKA i współaut. 2018).

Badanie, które zostało przeprowadzone na szczurach przez MAHESHWARI i wspólaut. (2011), miało na celu zbadanie aktywności bogatej w fenol frakcji liści rokitnika zwyczajnego (PRF), pod kątem właściwości hepatochronnych i antyoksydacyjnych. W badaniu wzięło udział 5 grup. Pierwszej podano wyłącznie sól fizjologiczna - grupa kontrolna pozytywna. Drugiej grupie podano $\mathrm{CCl}_{4}$ (tetrachlorometan, zwiazek chemiczny o właściwościach hepatotoksycznych) - grupa kontrolna negatywna. Grupom szczurów 3., 4. i 5., poza $\mathrm{CCl}_{4}$, podawano doustnie odpowiednio dawki PRF: $25 \mathrm{mg} / \mathrm{kg}, 50 \mathrm{mg} / \mathrm{kg}$, $75 \mathrm{mg} / \mathrm{kg}$ przez 7 dni. U szczurów $z$ grup 2.-5. zaobserwowano $\mathrm{w}$ badaniach histopatologicznych martwice, zwyrodnienie tłuszczowe po 24 godzinach od potraktowania $\mathrm{CCl}_{4}$. Po podaniu PRF stwierdzono wyraźne złagodzenie objawów marskości wątroby indukowanej przez $\mathrm{CCl}_{4}$. Wyniki te wyraźnie wskazuja na hepatochronne działanie PRF $z$ liści rokitnika zwyczajnego (MAHESHWARI i współaut. 2011, ZAKYNTHINOS i współaut. 2016).

\section{ROKITNIK ZWYCZAJNY A PRZYROST TKANKI TŁUSZCZOWEJ}

Badanie Guo i współaut. (2020) wykazało korelacje między odkładaniem się tkanki tłuszczowej a spożywaniem liofilizowanego proszku $z$ rokitnika zwyczajnego. U myszy karmionych liofilizowanym proszkiem wykazano zmniejszony przyrost tkanki tłuszczowej oraz poprawę składu chemicznego surowicy. Dodatkowo zaobserwowano wpływ diety na liczebność bakterii jelitowych. Zmniejszyła się liczba szkodliwych bakterii Gram-ujemnych, obligatoryjnych anaerobowych (bezwzględnie beztlenowych) Desulfovibrio, które wykazują właściwości prozapalne w przewodzie pokarmowym. Natomiast zwiększyła się liczba pożytecznych bakterii Akkermansia $z$ gromady Verrucomicrobia (nadal mało poznana) czy Gram-ujemnych pałeczek Bacteroides (które wchodza w skład naturalnej mikrobioty). W konsekwencji zaobserwowano zmiany w syntezie metabolitów wtórnych, takich jak: kwas octowy, propionowy i masłowy (GUO i współaut. 2020).

Wydaje się, że liofilizowane owoce $z$ rokitnika zwyczajnego moga być pomocne w leczeniu chorób związanych $z$ zaburzeniami odżywiania, takich jak zespół objadania się czy jedzenia nocnego, które prowadza do zwiększenia masy tkanki tłuszczowej (otyłości). Również poprzez modulację mikrobioty 
jelitowej moga poprawiać metabolizm lipidów $\mathrm{w}$ organizmie. Liofilizaty moga być podawane w postaci prebiotyków, które pobudzaja wzrost lub aktywność metaboliczna mikroorganizmów korzystnych dla organizmu, lub w postaci suplementów diety, które zawieraja znaczne ilości związków bioaktywnych wykazujące właściwości prozdrowotne (GUO i współaut. 2020).

\section{PODSUMOWANIE}

Rokitnik zwyczajny jest roślina o szerokim spektrum właściwości prozdrowotnych, co wynika $z$ bogatego składu chemicznego, który jednak jest różny u konkretnych odmian czy w częściach tej rośliny. Owoce sa doskonałym źródłem nie tylko witamin $\mathrm{C}, \mathrm{E}$, $\mathrm{D}, \mathrm{K}_{1}, \mathrm{~B}_{1}, \mathrm{~B}_{2}, \mathrm{~B}_{6}$ czy $\mathrm{B}_{9}$, lecz także lipidów, a nawet mikro- i makroelementów. Stąd też składem biochemicznym przypominaja owoce egzotyczne, takie jak aronia czy goja. Natomiast liście i nasiona, chociaż uboższe w zwiazki bioaktywne, poza witaminami oraz mikro- i makroelementami, zawieraja flawonole i karotenoidy, które sa antyoksydantami. Soki $z$ owoców rokitnika i oleje $z$ jego nasion sa doskonałymi produktami uzupełniającymi codzienna dawkę zapotrzebowania na mikro- i makroelementy oraz witaminy. Ze względu na wysoką zawartość antyoksydantów, które działaja antykancerogennie i antymutagennie, Elaeagnus rhamnoides (L.) A Nelson może być stosowany w profilaktyce prozdrowotnej. Szczególnie interesujące sa jednak najnowsze badania GuO i współaut. (2020), w których wykazano zależność między spożywaniem preparatów $z$ rokitnika zwyczajnego a zmniejszona akumulacja tkanki tłuszczowej u myszy. Jeżeli badania te będa kontynuowane u ludzi, może okazać się, że rokitnik zwyczajny będzie stosowany jako preparat zapobiegajacy nadmiernej otyłości.

\section{Streszczenie}

Elaeagnus rhamnoides (L.) A. Nelson ze względu na swój wyjątkowy skład chemiczny i szeroki zakres właściwości prozdrowotnych może okazać się pomocny w leczeniu chorób cywilizacyjnych. Dzięki obecności przeciwutleniaczy (witamina C, zwiąki fenolowe, w tym kwasy fenolowe i flawonoidy), rokitnik wykazuje właściwości antyoksydacyjne, które zmniejszaja ryzyko powstawania mutacji punktowych czy hamuja apoptozę komórek narażonych na stres oksydacyjny. Ponadto, roślina ta wykazuje właściwości hepatoochronne, kardioochronne i przeciwkancerogenne. Na rynku dostępne sa preparaty zarówno $z$ owoców rokitnika zwyczajnego (o cierpkim, gorzkim smaku), $z$ nasion (w formie olejów) oraz $z$ liści (w formie herbat ziołowych), które przez swój bogaty skład chemiczny idealnie nadaja się jako element uzupełniający codzienna dawkę zapotrzebowania na takie zwiazki jak mikro- i makroelementy czy witaminy.

\section{LITERATURA}

BANACH K., RUTKOWska B., GLiBOWski P., 2017. Polska „superżywność” $w$ prewencji chorób nowotworowych. Bromat. Chem. Toksykol., 2, 106-114.

BANYŚ K., KNOPCZYK M., BOBROWSKA-KORCZAK B., 2020. Znaczenie kwasu foliowego dla zdrowia organizmu człowieka. Farmacja Polska 76, 79-87.

BIENIEK A., KAWECKI Z., SZAŁKIEWICZ M., 2007. Plonowanie kilku odmian rokitnika zwyczajnego (Hippophae rhamnoides L.) w warunkach Warmii. Roczniki Akademii Rolniczej w Poznaniu, Ogrodnictwo 41, 275-278.

BośKO P., BIEL W., 2017. Właściwości lecznicze rokitnika zwyczajnego (Hippophaë rhamnoides L.). Postępy Fitoterapii, 18, 36-41.

CZERWONKA W., PUCHALSKA D., ZARZYCKA-BIENIAS R., LIPIŃSKA M., HABRAT A., POlUDNIAK S., 2019. Zastosowanie witaminy E w kosmetologii. Kosmetologia Estetyczna 8, 13-16.

GAEAZZKA-CZARNECKA I., KORZENIOWSKA E., CZARNECKI A., POLITOWSKI K., 2019. Modyfikacja zawartości polifenoli $w$ winach $z$ wykorzystaniem impulsowego pola elektrycznego. Przegl. Elektrotech. 1, 89-92.

GuO C., HaN L., Li M., Yu L., 2020. Seabuckthorn (Hippophaë rhamnoides) freeze-dried powder protects against high-fat diet-induced obesity, lipid metabolism disorders by modulating the gut microbiota of mice. Nutrients 12, doi: $10.3390 /$ nu12010265.

JAROSZ M., RYCHLIK E., STOŚ K., WIERZEJSKA R., WOJTASIK A., CHARZEWSKA J., MOJSKA H., SZPONAR L., SAJÓR I.., KŁOSIEWICZ-LATOSZEK L., CHWOJNowska Z., WAJSZCZYK B., SzOSTAK B. W., CYBULSKA B., KunACHOWICZ H., WOLNICKA K., PRZYGODA B. i współaut., 2017. Normy żywienia dla populacji Polski. Instytut Żywności i Żywienia.

Kaliniak A., Florek M., Skatecki P., 2015. Profil kwasów tłuszczowych miesa, ikry $i$ watroby ryb. Żywność Nauka Technologia Jakość 2, 29-46.

KowAlska A., WALKIEWICZ K., KozIEe P., MUC-WIERZGON M., 2017. Aflatoksyny - charakterystyka $i$ wpływ na zdrowie człowieka. Post. Hig. Med. Dośw. 71, 315-327.

KULCZYNNSKI B., GRAMZA-MICHAŁOWSKA A., 2016. Goji berry (Lycium barbarum): composition and health effects - a review. Pol. J. Food Nutrit. Sci. 66, 2, 67-75.

MAHESHWARI D. T., YogendRa Kumar M. S., VerMA S. K., Singh V. K., SingH S. N., 2011. An tioxidant and hepatoprotective activities of phenolic rich fraction of Seabuckthorn (Hippophae rhamnoides L.) leaves. Food Chem. Toxicol. 49, 2422-2428.

MALINOWSKA P., OLAS B., 2016. Rokitnik - roślina wartościowa dla zdrowia. Kosmos, 65, 285292

PIEAT B., ZADERNOWSKI R. 2016. Owoce rokitnika(Hippophae rhamnoides L.) - bogate źródło zwiazków biologicznie aktywnych. Post. Fitoter. $17,298-306$.

PIŁAT B., ZADERNOWSKI R., 2019. Rokitnik zwyczajny (Hippophaë rhamnoides L.) $w$ profilaktyce nowotworowej. Post. Fitoter. 20, 111-117.

SZYMCZAK P., 2020. Blog rolniczy, http://szymczaksad.com/g/rokitnik-oblepicha/.

RESICH-KOZIEE L., NIEMYSKA K., 2020. Zastosowanie oleju $z$ rokitnika $w$ kosmetologii. Kosmetologia Estetyczna 2, 187-191. 
RUdZIŃSKA M., PRZYBYLSKI M., 2019. Rola tłuszczu $w$ żywieniu człowieka. Pediatria i Medycyna Rodzinna 22, 182-188.

SKALSKI B., KONTEK B., Olas B., ZuchOWSKI J., StOchmal A., 2018. Phenolic fraction and nonpolar fraction from sea buckthorn leaves and twigs: chemical profile and biological activity. Future Medicinal Chemistry 10, doi: $10.4155 / \mathrm{fmc}-2018-0144$.

SKALSKI B., KONTEK B., ROLNIK A., OlAS B., StOCHMAL A., ZUCHOWSKI J., 2019. Anti-platelet properties of phenolic extracts from the leaves and twigs of Elaeagnus rhamnoides (L.) A. Nelson. Molecules 24, doi: 10.3390/molecules24193620.

SROKA Z., Gamina A., Cisowski W., 2005. Niskoczasteczkowe zwiazki przeciwutleniajace pochodzenia naturalnego. Post. Hig. Med. Dośw. $59,34-41$.

SZOPA A., KUBICA P., EKIERT H., 2017. Ekologia, skład chemiczny, działanie prozdrowotne oraz badania biotechnologiczne aronii czarnoowocowej (Aronia melanocarpa (Michx.) Elliott), aronii czerwonej (Aronia arbutifolia (L.) Pers.) aronii śliwolistnej (Aronia $\times$ prunifolia (Marsh.) Rehd.). Post. Fitoter. 18, 145-157.

TKACZ K., WOJDYŁO A.,TURKIEWICZ P. I., BOBAK Ł., NOWICKA P., 2019. Anti-oxidant and anti-enzy- matic activities of sea buckthorn (Hippophaë rhamnoides L.) fruits modulated by chemical component. Antioxidants 8, 618-634.

Turek K., TOMF-SARNA A., SŁUPski J., StojaK M., 2016. Aktywność przeciwutleniajaca soków $Z$ owoców rokitnika. ResearchGate 9, 89-100.

UlanowsKa K., Skalski B., Olas B., 2018. Rokitnik zwyczajny (Hippophae rhamnoides L.) jako źródto zwiazków o aktywności przeciwnowotworowej $i$ radioprotekcyjnej. Post. Hig. Med. Dośw. 72, 240-252.

URBANIAK S., KAŹMIERCZAK- BARAŃSKA J., KARWOWSKI T. B., 2019. Rokitnik zwyczajny (Hippophaë rhamnoides L.) jako skarbnica witaminy C. Post. Bioch. 65, 212-216.

WILCZYŃSKA A., RETEL M., 2011. Oszacowanie pobrania zwiazków fenolowych $z$ dieta $Z$ uwzglednieniem udziału miodów pszczelich. Probl. Hig. Epidemiol. 4, 709-712.

WILSON J., LOWERY R., 2017. The Ketogenic Bible. The authoritative guide to ketosis. Victory Belt Publishing Inc., Kanada.

ZAKYNTHINOS G., VARZAKAS T., PETSIOS D., 2016. Sea buckthorn (Hippophae rhamnoides) lipids and their functionality on health aspects. Nutrit. Food Sci. 4, 182-194.

KOSMOS Vol. 70, 1, 121-129, 2021

Jacek Biatecki, Bartosz Skalski, Beata Olas

Department of General Biochemistry, Institute of Biochemistry, Faculty of Biology and Environmental Protection, University of Łódź, 141/143 Pomorska Str., 90-236 Eódź, E-mail: jacek.bialecki@edu.uni.lodz.pl

\section{ELAEAGNUS RHAMNOIDES (L.) A. NELSON AS A SOURCE OF PROHEALTH COMPOUNDS}

\section{Summary}

Elaeagnus rhamnoides (L.) A. Nelson, due to its unique chemical composition and wide range of pro-health properties, may prove helpful in the treatment of civilization diseases. Due to the presence of antioxidants (vitamin $\mathrm{C}$, phenolic compounds, including phenolic acids and flavonoids), sea buckthorn exhibits antioxidant properties that reduce the risk of point mutations or inhibit apoptosis in cells exposed to oxidative stress. Moreover, the plant has hepatoprotective, cardioprotective and anti-carcinogenic properties. There are preparations available on the market from sea buckthorn berries (with a tart, bitter taste), seeds (in the form of oils) and leaves (in the form of herbal teas), which due to their rich chemical composition are ideally suited as an element supplementing the daily dose of demand on such compounds as micro- and macro-elements or vitamins. 